\title{
Educational Process of Families of Children with Special Needs from Diagnosis to Transition: Legal Regulations and Opinions on the Solution of Problems
}

Özge Sultan Balikçi , Eskişehir Osmangazi University, ozgesultant@gmail.com, ORCID: 0000-0003-46321275

Macid Ayhan Melekoğlu, Eskişehir Osmangazi University, macidayhan@gmail.com, ORCID: 0000-00029933-5331

\begin{abstract}
Working with individuals with special needs requires a systematic team effort. Families are among the most important members of this team in the education process of individuals with special needs. The active participation of the families of children with special needs (CSN) in all aspects of the special education process is indispensable for their children to succeed in academic and social fields. However, studies on the awareness of their families about the legal rights of CSN are very limited. The aim of this study is to examine the opinions of the families of CSN about their rights in the education and training processes and the solutions of the problems they face. Qualitative research design was used in the research and the data were analyzed by content analysis method. The research data were collected through semi-structured interviews. The results of the research revealed that parents of CSN have limited knowledge about the legal rights of their children and encounter problems with special education services.
\end{abstract}

Keywords: Individuals with special needs, Families, Legal regulations Received: 15.11.2020 Accepted: 05.12.2020 $\quad$ Published: 16.01.2021

\section{INTRODUCTION}

The importance of establishing positive relationships between families and experts in education has been known for a long time (Summers, Gavin, Hall \& Nelson, 2003). In positive relationships, families are accepted as working partners. The partnership is defined as mutually supportive interactions between families and experts (Blue-Banning, Summers, Frankland, Nelson, \& Beegle, 2004). Working partnerships, however, focus on meeting the needs of children and families. Research shows that family involvement supports cognitive development and increases academic success of their children (Desimone, 1999; Halle, Kurtz-Costes, \& Mahoney, 1997; Simon, 2001; Trusty, 1999). In addition, family participation in special education is very important for success of their children in both school and social life.

Family participation, which is considered as a positive experience for education, is accepted as a very important part of the education of children with special needs (Fish, 2008; Reiman, Beck, Coppola, \& Engiles, 2010). Thanks to family participation, families offer parental support for the education of their children with special needs. In addition, it is stated that there is an increase in the satisfaction of families with special education services to overcome the difficulties that families and experts face together (Mueller, Singer, \& Draper, 2008).

The families of children wih special needs face more difficulties than the problems of their children. Although they do their best, families may miss what they need to know to defend themselves and their children in some cases (Cheatham, Hart, Malian, \& McDonald, 2012). For this reason, families need to know the legal regulations in order to cooperate with special education specialists and to notice possible violations (Phillips, 2008). In addition, families are expected to be informed about legal regulations (Lai \& Vadeboncoeur, 2013) in order to defend their children's rights.

Article 42 of the Constitution of Republic of Turkey states that individuals who need special education have the right to education and training, and addresses equality of opportunity (Vural \& Yücesoy, 2003). However, it is emphasized that the education services offered to individuals with special needs should be performed in accordance with human rights (Vural \& Yücesoy, 2003). However, families undertake the advocacy of legal rights of individuals with special needs. At the same time, the importance of family participation in special education has been further strengthened by the Special Education Services Regulation (Ministry of National Education [MoNE], 2006), which requires parents to participate in the educational decisions. Nevertheless, it is stated that there are problems arising from the lack of knowledge among teachers and families (Akçamete, Büyükkarakaya, Bayraklı, \& Yıldırım, 2012). 
Awareness of the legal rights of families of CSN can increase the effectiveness of special education. It is inevitable for the families of CSN to participate actively in all aspects of the special education process. In the special education process, knowing the rights of families and their children can help to increase the quality of special education practices. For this reason, the aim of the study is to examine the opinions of the families of CSN about their rights in the education and training processes and the solutions of the problems they face. Therefore, the sub-objectives of this research are:

1. What are the opinions and suggestions of the families of children with special needs regarding the diagnosis process and legal regulations?

2. What are the opinions and suggestions of the families of children with special needs regarding placement in educational settings and the legal regulations?

3. What are the opinions and suggestions of families of children with special needs regarding individualized education program preparation process and legal regulations?

4. What are the opinions and suggestions of families of children with special needs regarding the education process of their children and legal arrangements?

5 . What are the opinions and suggestions of families of children with special needs regarding the transition process and legal regulations?

\section{METHOD}

Qualitative research design was used in this study to determine the views of families of children with special needs regarding the legal regulations in the education and training processes and the solution of the problems they face (Yıldırım \& Şimsek, 2011). Data obtained through qualitative research help understand individuals with special needs and team members who provide special education services (Brantlinger, Jimenez, Klingner, Pugach, \& Richardson, 2005). For this reason, in this study opinions and suggestions of the families of CSN about their legal rights in the education and training process were examined. The data of this study were collected through a semi-structured interview method because the method allows asking additional questions and explanations and obtaining in-depth information in order to determine the views and suggestions of families about their legal rights in terms of their CSN. With the interview technique, it is aimed to reveal thoughts, attitudes, wishes and reactions by asking determined questions about individuals on a subject (Yıldırım \& Şimşek, 2011). Semi-structured interview method, which is one of the interview techniques, has the opportunity to express itself to the participant, the analysis of the data is easy and it has the advantage of obtaining detailed information when necessary (Büyüköztürk, Kılıç Çakmak, Akgün, Karadeniz, \& Demirel, 2012). Specifically, in this study, open-ended questions were asked to the families about the diagnosis, placement, preparation of an individualized education program, and transition periods in semi-structured interviews. For semi-structured interview questions prepared for use in interviews, expert opinions were received from five experts. The data obtained as a result of the interviews were analyzed with the content analysis method. In qualitative research, it refers to the close examination of texts to understand content analysis themes or perspectives (Brantlinger et al., 2005). The research data were carried out with families of CSN in the city center of Eskişehir province. Demographic information of the participants is summarized in Table 1.

\section{Participants}

The data were collected from families of CSN living in the city center of Eskişehir. Detailed demographic information about the participants of this study is outlined in Table 1.

Table 1. Demographic information of the participants

\begin{tabular}{|l|l|l|l|l|l|}
\hline $\begin{array}{l}\text { Diagnosis of } \\
\text { the child }\end{array}$ & $\begin{array}{l}\text { The age of } \\
\text { the child }\end{array}$ & $\begin{array}{l}\text { The degree of } \\
\text { proximity } \\
\text { and code }\end{array}$ & $\begin{array}{l}\text { Education } \\
\text { status }\end{array}$ & Profession & Age \\
\hline $\begin{array}{l}\text { Multiple } \\
\text { Disabilities }\end{array}$ & 2 & Mother 1 & High school & $\begin{array}{l}\text { Bank } \\
\text { employer }\end{array}$ & 35 \\
\hline $\begin{array}{l}\text { Intellectual } \\
\text { Disabilities }\end{array}$ & 13 & Father 2 & $\begin{array}{l}\text { Middle } \\
\text { school }\end{array}$ & Laborer & 55 \\
\hline
\end{tabular}




\begin{tabular}{|l|l|l|l|l|l|}
\hline $\begin{array}{l}\text { Specific } \\
\text { Learning } \\
\text { Disabilities }\end{array}$ & 12 & Father 3 & High school & Driver & 41 \\
\hline $\begin{array}{l}\text { Intellectual } \\
\text { Disabilities }\end{array}$ & 6 & Mother 4 & University & Officer & 38 \\
\hline Autism & 10 & Mother 5 & $\begin{array}{l}\text { Primary } \\
\text { school }\end{array}$ & Housewife & 40 \\
\hline Autism & 12 & Mother 6 & $\begin{array}{l}\text { Primary } \\
\text { school }\end{array}$ & Housewife & 40 \\
\hline Autism & 3 & Mother 7 & University & Nurse & 35 \\
\hline $\begin{array}{l}\text { Hearing } \\
\text { Disabilities }\end{array}$ & 5 & Mother 8 & University & Teacher & 34 \\
\hline $\begin{array}{l}\text { Intellectual } \\
\text { Disabilities }\end{array}$ & 27 & Mother 9 & High school & Housewife & 53 \\
\hline $\begin{array}{l}\text { Multiple } \\
\text { Disabilities }\end{array}$ & 11 & Father 10 & University & Soldier & 40 \\
\hline
\end{tabular}

Table 1. (continues)

\begin{tabular}{|l|l|l|l|l|l|}
\hline $\begin{array}{l}\text { Diagnosis of } \\
\text { the child }\end{array}$ & $\begin{array}{l}\text { The age of the } \\
\text { child }\end{array}$ & $\begin{array}{l}\text { The degree of } \\
\text { proximity and } \\
\text { code }\end{array}$ & $\begin{array}{l}\text { Education } \\
\text { status }\end{array}$ & Profession & Age \\
\hline $\begin{array}{l}\text { Physical } \\
\text { Disabilities }\end{array}$ & 12 & Mother 11 & High school & Housewife & 35 \\
\hline $\begin{array}{l}\text { Intellectual } \\
\text { Disabilities }\end{array}$ & 9 & Mother 12 & Middle school & Housewife & 34 \\
\hline Autism & 5 & Mother 13 & University & Teacher & 35 \\
\hline $\begin{array}{l}\text { Intellectual } \\
\text { Disabilities }\end{array}$ & 6 & Mother 14 & University & $\begin{array}{l}\text { Bank } \\
\text { employer }\end{array}$ & 34 \\
\hline Autism & 6 & Father 15 & College & Imam & 36 \\
\hline $\begin{array}{l}\text { Physical } \\
\text { Disabilities }\end{array}$ & 13 & Mother 16 & $\begin{array}{l}\text { Primary } \\
\text { school }\end{array}$ & Housewife & 43 \\
\hline $\begin{array}{l}\text { Intellectual } \\
\text { Disabilities }\end{array}$ & 19 & Mother 17 & High school & Housewife & 43 \\
\hline $\begin{array}{l}\text { Physical } \\
\text { Disabilities }\end{array}$ & 34 & Father 18 & University & Retired & 60 \\
\hline
\end{tabular}

\section{Data collection tool}

In the research, semi-structured interview questions were used as data collection tool. Questions were asked to reflect the experiences, opinions and suggestions of families of CSN regarding the diagnosis, placement, education, individualized education plans and transition processes. During the preparation of interview questions, the researchers came together and examined the Special Education Services Regulation (MoNE, 2006) as a source of legal regulations and determined the questions by considering the education services included in this regulation. For the interview questions, expert opinion was received 
from five different people who completed their doctorate in educational sciences or special education, and the semi-structured questions prepared were finalized.

\section{Data Analysis}

It is stated that qualitative studies reflect silent individuals and focus on the individual meanings of the people participating in the studies (Brantlinger et al., 2005). For this reason, in this study, the opinions and suggestions of the families of CSN about their legal rights in the process from the diagnosis to the transition period were examined through content analysis. Content analysis is used to reach the concepts and relationships that can explain the collected data from the study (Yıldırım \& Şimşek, 2011). The participants were families from three different private special education and rehabilitation centers. The interviews were conducted in those centers with families. The interview lasted between 30 and 45 minutes. Voice recordings of the interviews were transcribed. The names of the families in the study were kept anonymous and their names were coded in numbers. Written records of the interviews are numbered one by one. Written documents are examined and content items are created by the researchers. Researchers came together and reached consensus for the reliability of the themes and sub-themes created as a result of the examination.

\section{RESULTS}

The opinions of the families of CSN about their legal rights and suggestions about their identification, placement, individualized education plans, education and transition processes were determined. The data obtained as a result of semi-structured interviews with the families are examined and the themes and subthemes reached are given in the following section.

\section{Diagnostic Process}

Table 2. Diagnosis process

\begin{tabular}{|c|c|c|}
\hline Diagnostic Process & $\begin{array}{l}\text { Legal rights in the diagnostic } \\
\text { process }\end{array}$ & $\begin{array}{ll}\text { Diagnosis } & \text { process } \\
\text { recommendations } & \end{array}$ \\
\hline Families own search $(n=6)$ & Lack of knowledge $(n=14)$ & $\begin{array}{l}\text { Awareness raising study for } \\
\text { early diagnosis }(n=2)\end{array}$ \\
\hline Health board $(n=6)$ & Course hours and fees $(n=2)$ & $\begin{array}{l}\text { Family support and information } \\
(n=7)\end{array}$ \\
\hline $\begin{array}{l}\text { Educational diagnosis of } \\
\text { Guidance \& Research Center } \\
{[\mathrm{GRC}](n=6)}\end{array}$ & $\begin{array}{l}\text { Tax exemption in vehicle } \\
\text { purchase }(n=1)\end{array}$ & $\begin{array}{lll}\text { Psychological } & \text { support } & \text { to } \\
\text { families }(n=4) & & \end{array}$ \\
\hline House visit $(n=2)$ & Free electric \& water $(\mathrm{n}=1)$ & Orientation $(n=3)$ \\
\hline Meeting the expectation $(n=1)$ & Right to be re-identified $(\mathrm{n}=1)$ & $\begin{array}{l}\text { More expert opinion and } \\
\text { detailed assessment }(n=6)\end{array}$ \\
\hline \multirow[t]{4}{*}{ Meeting the expectation $(n=1)$} & State payment $(\mathrm{n}=1)^{*}$ & Support education $(\mathrm{n}=1)$ \\
\hline & Maintenance fees $(n=1)$ & Increase function $(n=1)$ \\
\hline & & Increase option $(n=1)$ \\
\hline & & Facilitating the process $(n=1)$ \\
\hline
\end{tabular}

The participants explained the units and the steps they followed about the diagnostic process. The majority of the participants stated that they started the diagnostic process with their own search. Some of the participants mentioned the difficulties they faced during the diagnostic process. However, one participant stated that their expectations were met after their diagnosis for their children.

8: This process was the most painful process we went to the guidance and research center. The doctor asked for the report. We received the doctor's report, they determined a program based on 
the result from the doctor's report. Along with the specified program, they directed us to a private special education and rehabilitation center. In this way, the process started.

9: When I got the diagnosis, I said, I found exactly what I was looking for."

\section{Legal rights in the diagnostic process}

Regarding the legal rights related to diagnosis, most of the participants stated that they did not know about their legal rights. Regarding legal rights, the participants also stated that they have information about course fees.

6: I didn't know what my legal rights were. As it happened to us, we learned over time. The state is able to get the tests done at the university hospital in every condition. We can also take special education. So as I said, I know where I can go now. We know how to train them.

11: If a small state hospital decides to be diagnosed and the family does not accept this, a different doctor, as a referee, can re-diagnose in another hospital for a misdiagnosis after applying to the provincial health committee.

\section{Diagnostic process recommendations}

Many of the participating families expressed their need for support and information regarding the recommendations for the diagnostic process.

1: The last point should be placed by being examined by many expert.

5: I think that the family should be supported as well, and I think that the family should not be left alone.

In addition, the families also mentioned that they want to be supported psychologically by stating the difficulties they encounter in the identification process.

2: Our only point missing now is psychological support, and certainly families should be given psychological support.

7: Well, families need education. Families should be informed because the families are suffering the biggest problem. That is, they should be enlightened, and they should be facilitated. They should be supported morally. But it is a very difficult process.

Parents also made recommendations regarding the evaluation of their children by more experts in a wider time period, in a more comprehensive and detailed manner during the diagnosis process.

10: Awareness creating works should be carried out for early diagnosis, and generally the focus of the immigrant population will be given.

11: More detailed tests should be done during the diagnosis process. Random diagnosis should not be made and the family should be offered solutions.

17: Most doctors come and look at fifteen minutes. I think they cannot get out that in fifteen minutes, so this child needs to be examined at least for an hour or so. So I do not believe that the diagnosis will be made there in ten minutes, it needs at least an hour for specialists to understand. It should be that way.

\section{Placement in Educational Environments}

Table 3. Placement in educational environments

\begin{tabular}{|c|c|c|}
\hline $\begin{array}{l}\text { Process of Placement in } \\
\text { Educational Environments }\end{array}$ & $\begin{array}{l}\text { Legal rights in the placement } \\
\text { process }\end{array}$ & $\begin{array}{l}\text { Recommendations for placement } \\
\text { process }\end{array}$ \\
\hline $\begin{array}{l}\text { Families own search }(\mathrm{n}=11) \\
\text { GRC }(\mathrm{n}=5) \\
\text { Health board report }(\mathrm{n}=2) \\
\text { Institution and teacher }(\mathrm{n}=2) \\
\text { Direction of the Directorate of } \\
\text { National Education }(\mathrm{n}=2)\end{array}$ & $\begin{array}{l}\text { Lack of knowledge }(\mathrm{n}=11) \\
\text { Course fees / payments }(\mathrm{n}=3) \\
\text { Choosing and changing } \\
\text { educational institutions }(\mathrm{n}=3) \\
\text { Inclusion right }(\mathrm{n}=1) \\
\text { Supportive training hour }(\mathrm{n}=1)\end{array}$ & $\begin{array}{l}\text { More informing studies }(\mathrm{n}=10) \\
\text { Quality of education }(\mathrm{n}=3) \\
\text { Trainings in the institution are } \\
\text { standard }(\mathrm{n}=3) \\
\text { Written information }(\mathrm{n}=2) \\
\text { No discrimination in inclusion ( } \\
=1 \text { ) } \\
\text { Home education }(\mathrm{n}=1)\end{array}$ \\
\hline
\end{tabular}




\section{Placement process}

Participants in the study stated that they usually place their children in schools as a result of their own search, GRS and teachers' guidance. Families also mentioned about the difficulties experienced with their CSN during their placement in educational settings.

15: Fight-fight. Guidance and Research Center decided inclusion. Psychiatry gave a letter saying that he should be trained in a special education classroom for 2 years. Guidance and Research Center then sent us to a special education classroom.

\section{Legal rights in the placement process}

Most of the families participating in the study stated that they do not have any information about the legal rights they have in the process of placing their CSN in educational settings.

9: No, we didn't know. By searching, we have reached some information. Now that is not completely clear but more or less.

5: So I don't know very much, I just knew that I knew we could go to that school if the GRC placed it. I did not know much, still not. Obviously, we did not go into a lot of search unless we had trouble. The families also mentioned that their children were paid with the support of the state and that they had the right to support education and inclusion.

11: At the beginning, we did search with my wife. How will your support education be and what stages will we go through? We scanned and read how many hours of education and laws on people with disabilities. We even examined examples of the areas of use of these laws. We heard several cases of child abuse.

However, families stated that they had the right to choose an institution during the placement process in educational environments.

9: We started school under very difficult conditions. We were in Ankara then Buse was not accepted by any school. Especially a normal school ... never accepted as a special education classroom. Then we went to GRC. We also waited in line in GRC. We waited for about two and a half years. We forced ourselves to be accepted.

\section{Placement diagnostics process recommendations}

Families of CSN referred to the most information and guidance activities regarding their suggestions for the placement process.

1: Families should be informed in detail and illuminated. People who already have children with disabilities cannot find the time to go out to take care of the child.

14: Serious guidance and awareness raising should be done.

The families also stated that they wanted the information to be made in writing. They also stated that the trainings in the institutions should be provided in a standard way and the education provided should be of high quality.

8: As I just said, definitely at least one text should be given containing the rights. In other words, if you say it like that, if it happens like that, if it happens like this. This situation should not be at the mercy of people. It must be a list of what has been told to us or an institution. It should have a list in public schools rather than private centers. There are many special education institutions and around forty institutions. But if I am not mistaken, the number of institutions where the state can provide training is three.

\section{Individualized Education Plan (IEP) Preparation}

Table 4. Individualized education plan (IEP) preparation

\begin{tabular}{|c|c|c|}
\hline IEP Preparation Process & $\begin{array}{l}\text { Legal rights in the IEP } \\
\text { preparation process }\end{array}$ & $\begin{array}{l}\text { Suggesstions for IEP preperation } \\
\text { process }\end{array}$ \\
\hline $\begin{array}{l}\text { The family is also in the team }(n= \\
5) \\
\text { Setting goals according to the } \\
\text { child's needs and level }(n=4) \\
\text { Having team work }(n=3) \\
\text { Plan prepared by the institution ( } \\
=1 \text { ) }\end{array}$ & $\begin{array}{l}\text { Not having knowledge }(\mathrm{n}=14) \\
\text { Preparation is mandatory }(\mathrm{n}= \\
\text { 4) } \\
\text { Information is mandatory }(\mathrm{n}= \\
\text { 1) }\end{array}$ & $\begin{array}{l}\text { Informing family }(\mathrm{n}=2) \\
\text { Communication / language and } \\
\text { speech support }(\mathrm{n}=1) \\
\text { The child's updated functional } \\
\text { needs }(\mathrm{n}=4) \\
\text { Active participation of the family } \\
(\mathrm{n}=3)\end{array}$ \\
\hline
\end{tabular}




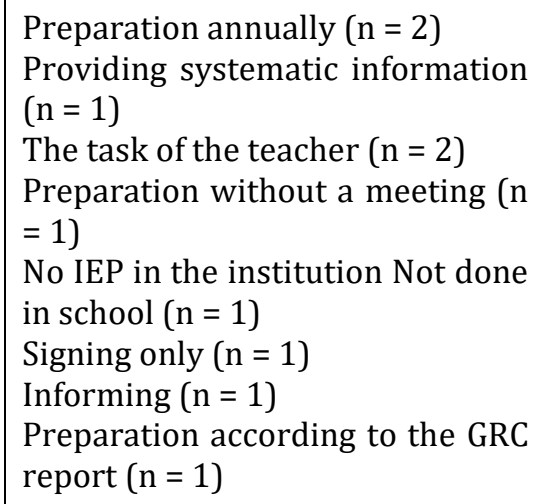

\section{IEP preparation}

Families mostly mentioned that the process of preparing IEP for CSN is a team work and that the family should also be involved in this process.

5: You know, there must be a team in this. I have to be in that team. Behold, I know that there should be people from the school administration and a teacher. But I cannot attend because I worked because I could not attend. We have already talked about this.

Parents stated that the task of preparing IEP belongs to the teacher and that the IEPs have goals suitable for their child's needs and levels.

10: The duty of the teacher of the IEP in the school. But there are no meetings held. In the institution, IEP is not prepared. We also support with private lessons at home. IEP is unnecessary due to the low number of hours in the institution.

9: When we go to get a report, I know what they wrote in that file. It is written that he can do it, he can hold it. I do not know exactly.

Participating families also stated that IEPs were prepared annually, signed and families were informed about IEP.

13: In elementary schools, there are no knowledgeable teachers like educators in private institutions and teachers do not have sufficient information.

8: It is early for public school, but those in the institution should prepare it. It is a one-year training plan. I am constantly informed. Good training, but the rest is not important.

2: I saw IEP only when the parent's signature had to be signed.

\section{Legal rights in the IEP preparation process}

Many of the families in the study stated that they do not have any information about their legal rights in the process of preparing IEP for their CSN.

3: We don't know them either. More precisely, we send but we do not know the legal rights.

Families who have knowledge of legal rights stated that the process of preparing and informing the IEP is compulsory.

8: I know that the disability in the doctor's report is determined according to the type of education in the previous year.

10: Information about the preparation of IEP and training is compulsory.

11: It has to be prepared but the required sensitivity is not shown.

\section{IEP preparation process recommendations}

Families of CSN stated that families should be at the center by actively participating in the process by teachers to prepare IEP regarding their suggestions for the IEP preparation process.

14: By actively participating in the family, an evaluation should be made by considering the functional needs of the child.

15: If IEP is applied, I must have knowledge of it. In order to implement the same IEP in school at home, the family must also receive education.

Families also stated the detailed assessment of the child while preparing the IEP and updating the IEP according to the needs of the child.

8: IEP should not be fixed, it should be prepared according to its requirement. If the doctor's report says hearing impaired, for example, you have a single module and a single chance for children of that age. If the child has multiple disabilities, the system is stuck and cannot do anything. 


\section{Education process}

Table 5. The child's education

\begin{tabular}{|c|c|c|}
\hline Education Process & $\begin{array}{lll}\text { Education Process } & \text { Legal } \\
\text { Rights } & & \end{array}$ & Training Process Suggestions \\
\hline $\begin{array}{l}\text { Doing homework / repeating }(\mathrm{n}= \\
\text { 13) } \\
\text { Getting information at the end of } \\
\text { each lesson }(\mathrm{n}=11) \\
\text { Getting information by talking to the } \\
\text { teacher }(\mathrm{n}=6) \\
\text { Gettinging information by phone } \\
\text { and in writing }(\mathrm{n}=2) \\
\text { Material supply }(\mathrm{n}=2) \\
\text { Getting information by meeting } \\
\text { once a month }(\mathrm{n}=1) \\
\text { Receiving written information } \\
\text { (institution) }(\mathrm{n}=1) \\
\text { Covering the education cost of } \\
\text { tutor/teacher }(\mathrm{n}=1)\end{array}$ & $\begin{array}{l}\text { Not having knowledge ( } \mathrm{n}= \\
11) \\
\text { Compulsory course hours ( } \mathrm{n} \\
=3 \text { ) } \\
\text { Course fees covered by the } \\
\text { state }(\mathrm{n}=1) \\
\text { The right to education }(\mathrm{n}=1) \\
\text { Right to choose a school }(\mathrm{n}= \\
\text { 2) }\end{array}$ & 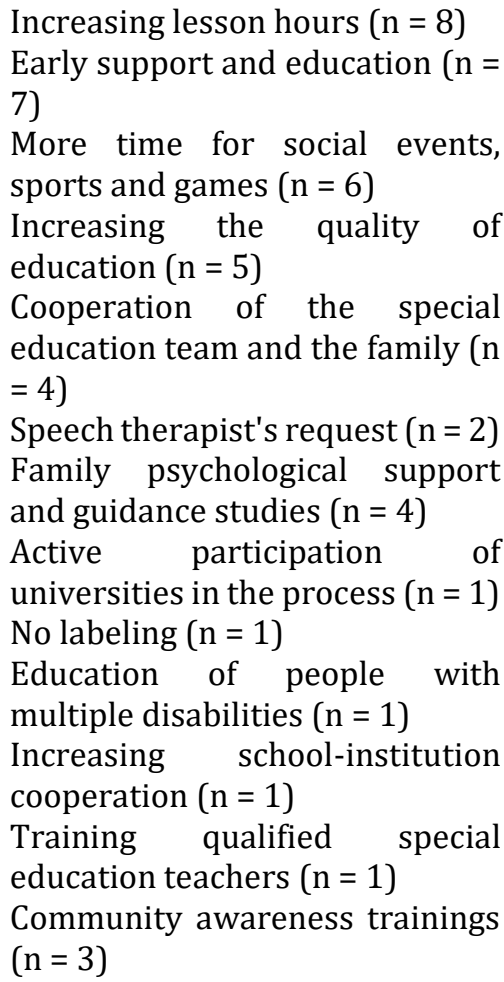 \\
\hline
\end{tabular}

While most of the families participating in the study stated that they received face-to-face information at the end of each lesson regarding the information interval during the education process, other families stated that they met monthly by phone.

6: We have family trainings every month and they call me in family trainings. I am informed about the level of the child. They tell me what kind of process I should follow during that month, what topics I should take and how I should teach. In a month, I schedule a program on what my child should tell. Every day we routinely study with 15 minutes or half an hour.

Some families stated that they received information about the education process of their CSN by talking to their teachers over the phone and in writing.

3: When we go, we get information from the school when we go ourselves. Of course, they send the trainings they did after that, put them in their bags. We have nothing with the school, we have no problems. But I try to learn when I go to school individually.

In addition, the families mentioned that their CSN participated in the education processes by helping them do their homework and repeating.

3: We try to take care at home and help in their lessons. Then we try to make him talk. But we could not successful in making him talk. In other words, we cannot make him speak because he is stubborn.

8: At least we get the missing educational materials and things that should be present in the school. We try to understand and apply the trainings that teachers recommend. This style.

\section{Legal rights in the education process}

Many of the families participating in the study stated that they do not know the legal rights of their CSN in the educational process. The families also stated that there is a certain class hour to be given to their children, education fees are covered by the state and they have the right to send their children to the institution of their choice. 
8: Education is under state guarantee. If they cannot take the class hours, they can apply to the required places and this will have a serious sanction.

6: I don't know much, frankly. The only thing I know is that they should be checked regularly at university hospitals and I can send them to any school I want.

\section{Suggestions for the education process}

Parents made suggestions for the educational processes of their CSN mostly about increasing the education hours and quality of education,

5: I think we receive special education for two hours a week. In my opinion this is insufficient. What should I know? It should be increased. I think there must be a cooperation between the school and the place.

17: Education should be more intensified and given. Support training period is insufficient. 8 hours is not enough.

Families also highlighted the importance of cooperation with families in the education process. Nevertheless, families have suggested that children start their educational processes early and provide support.

14: All teachers working for the child should be in cooperation in the education process. There should be no labeling during the training process.

Some families stated that they expect psychological support and guidance studies throughout the education process.

9: Children should receive support education in different dimensions such as psychology, not only in school lessons academically.

Parents stated that they need social activities such as sports and games for their children as well as education.

19: Social activities, sports activities can take place. The game can be taught by spending more time on the game. He can play with children like himself.

20: It should be brought to life with plenty of activities. Work should be done in order to accustom people outside to children with disabilities.

8: Different supports should be given. Support can be provided to families as soon as they hear down syndrome and subsequently experience it. After the acceptance process, guidance work should be done.

\section{Transition Process}

Table 6. Transition process

\begin{tabular}{|c|c|c|}
\hline Planning the transition process & $\begin{array}{l}\text { Legal rights in the transition } \\
\text { process }\end{array}$ & $\begin{array}{l}\text { Suggestions for the transition } \\
\text { process }\end{array}$ \\
\hline $\begin{array}{l}\text { No planning }(n=6) \\
\text { Continiue inclusive classroom (n } \\
=3 \text { ) } \\
\text { Continue to the special education } \\
\text { classroom }(n=2) \\
\text { Support training }(n=3) \\
\text { Vocational training }(n=3) \\
\text { University }(n=1) \\
\text { With lifetime family support }(n= \\
\text { 1) } \\
\text { Pause }(n=1)\end{array}$ & $\begin{array}{l}\text { Not having knowledge }(n=17) \\
\text { The obligation of businesses to } \\
\text { work with disabilities }(n=1)\end{array}$ & $\begin{array}{l}\text { Vocational training }(n=5) \\
\text { Increased support for inclusion (n } \\
=5) \\
\text { Family support }(n=4) \\
\text { Orientation }(n=3) \\
\text { Quality education }(n=2) \\
\text { Informing }(n=2) \\
\text { Choosing a suitable school for the } \\
\text { child }(n=1) \\
\text { Nursing home }(n=1) \\
\text { Life coaching }(n=1) \\
\text { Continuous evaluation }(n=1)\end{array}$ \\
\hline
\end{tabular}

\section{Planning the transition process}

Most of the families in the study stated that they did not have a transition plan for their CSN.

3: I don't have a plan yet. I mean, if there are no teachers, I cannot decide for myself according to myself.

Some families stated that they plan to continue their inclusive and supportive education, while some families stated that they intend to send them to vocational education. 
10: We plan to send it to vocational education schools and receive an apprenticeship training elsewhere. It will only work in a place where people with disabilities work, accompanied by life coaches.

5: He is my teacher going to the third grade now, if our teacher is not determined, we are very pleased with our teacher. He also made a good inclusion with his friends very good. In my opinion inclusion is already that not only the child with disability socialize with normal children, but also it is necessary for children without disabilities socialize with CSN.

\section{Legal rights in the transition process}

Parents stated that they do not have information about the legal rights of their CSN regarding the transition process. One of the families mentioned that workplaces are obliged to employ people with special needs by placing them in their work areas.

10: After the state has met up to high school level, it can be an education like apprenticeship by continuing with support education. Workplaces have an obligation to employ people with disabilities on a particular employee.

\section{Suggestions for the transition process}

The families in the study suggested that there are institutions for vocational training of their children. They mentioned that different areas such as apprenticeship training can be arranged for individuals with special needs.

2: Only schools such as vocational high schools for these children should be opened.

1: A job that they can work at the level they can do should be given.

3: There may be jobs related to hand skills. I don't know, I didn't get any information about it. I don't know what to do.

Families also emphasized the need for increasing support for inclusive education, informing and guiding families during the transition process.

8: At least we should be informed. We want to be informed. Legal right is all right what is available. But instead of hearsay information, as we can see in a way that we will know in a more verbal way, or refer to us as see here.

9: Teachers in state schools are required to provide quality education.

Some families stated that they should be supported with their children regarding the transition processes.

18: We will always be dependent on us, we would like to be supported in this regard.

7: Well, the biggest burden is on mothers. The burdens on mothers should be lightened. At least there should be a place like a nursing home where mothers can leave when they have a thing to do. I can leave it for an hour or two during the day, for example.

\section{CONCLUSION AND DISCUSSION}

The aim of the study is to determine the opinions of the families of CSN regarding their legal rights in the education and training processes and the solution of the problems they face. During the interviews held for this purpose, the families answered the questions about their experience, opinions and suggestions on the legal rights regarding the identification process, placement process, education process and transition process.

Families addressed the difficulties they faced during dioagnosis and educational process. Similar to these findings, Yassibaş and Çolak (2019) mentioned that families have different difficulties in the educational processes and diagnosis process of their CSN.

The families participating in the study stated that there should be team work in the educational processes of their CSN. However, many studies emphasize the importance of family involvement and team work in the educational process (Blue-Banning et al., 2004; Desimone, 1999; Halle et al., 1997; Simon, 2001; Summers et al., 2003; Trusty, 1999).

Parents stated that they needed support in attending training and guidance during the interviews. Research shows that as families and teachers overcome the difficulties they face in supporting their children's education, families' satisfaction with special education services increases (Mueller et al., 2008).

Some of the families of CSN may be unaware of their rights to defend themselves and their children (Cheatham et al., 2012). In this study, it was revealed that the families' knowledge about the legal rights of their CSN is quite insufficient.

The importance of family participation in special education is emphasized by the Special Education Services Regulation (MoNE, 2006), which gives parents the right to participate in the education decision. 
However, as a result of the increase in the number of students involved in mainstreaming practices, it is stated that there are information deficiencies among families (Akçamete et al., 2012). The families participating in the study stated that their CSN need information from many different areas from diagnosis to transition.

In a study conducted in order to determine the needs of families of children with hearing impairments in the transition to kindergarten in preschool period, the families stated that they need information about their legal rights regarding the admission of their children to educational environments (Kargın, Akçamete, \& Baydık, 2001). In parallel with these findings, it was stated that most families need information about transition.

The families of children with special needs emphasized that they needed information and support during the education process of their children (Akçamete \& Kargın, 1996; Tekinarslan \& Bircan, 2009). In parallel with these findings the families who participated in this study stated that they needed guidance and educational support for their children.

Parents also stated that they are not satisfied with the quality of their special needs education and the education they receive (Selimoğlu, Özdemir, Töret, \& Özkubat, 2013). In the study conducted in parallel with these findings, families emphasized that the quality of the education received by their CSN should be increased.

It is stated that providing educational services to individuals with special needs can contribute to equal opportunities and make the social structure more democratic (Vural \& Yücesoy, 2003). It is recommended to conduct research on the reflection of legal arrangements made with special education and CSN on practices (Vural \& Yücesoy, 2003). However, it is predicted that informing and directing families about their CSN can be very beneficial in terms of reducing the stress that families experience and contributing to the education of their children (Akçamete \& Kargın, 1996).

The results of the research have shown that parents with CSN have limited knowledge of their legal rights in many areas such as their identification, placement in educational settings, preparation of IEP, general education and transition processes. The support to be provided to families of CSN on the legal rights of their children is expected to have a positive impact on children's education. However, it is seen as very important to include legal awareness studies within the scope of family education services. Workshops on families' arrangements and updates can be held in line with legal awareness studies. Information meetings can be planned regarding the legal rights of CSN for families. At these meetings, regulations and laws related to their existing rights can be compiled systematically and presented in written form. Increasing the guidance activities in all processes from their diagnosis about their CSN to families and directing their families to research on their legal rights about their children. It is envisaged that raising awareness of families of CSN who are legal advocates in terms of their children and their legal rights will increase the special education services and support services of these children and thus the quality of life of both them and their children.

\section{REFERENCES}

Akçamete, G., Büyükkarakaya, H. S., Bayraklı, H., \& Yıldırım, E. S. (2012). The reflections of education policy: General and special education [Eğitim politikalarının yansımaları: Genel ve özel eğitim]. Educational Sciences \& Practice, 11(22), 191-208.

Cheatham, G. A., Hart, J. E., Malian, I., \& McDonald, J. (2012). Six things to never say or hear during an IEP meeting: Educators as advocates for families. Teaching Exceptional Children, 44(3), 50-57. doi: $10.1177 / 004005991204400306$

Fish, W. W. (2008). The IEP meeting: Perceptions of parents of students who receive special education services. Preventing School Failure: Alternative Education for Children and Youth, 53(1), 8-14.

Mueller, T. G., Singer, G. H., \& Draper, L. M. (2008). Reducing parental dissatisfaction with special education in two school districts: Implementing conflict prevention and alternative dispute resolution. Journal of Educational and Psychological Consultation, 18(3), 191-233.

Phillips, E. (2008). When parents aren't enough: External advocacy in special education. The Yale Law Journal, 117(8), 1802-1853. doi: 10.2307/20454695

Reiman, J. W., Beck, L., Coppola, T., \& Engiles, A. (2010). Parents' experiences with the IEP process: Considerations for improving practice. Eugene, OR: Center for Appropriate Dispute Resolution in Special Education (CADRE).

Yıldırım, A., \& Şimşek, H. (2013). Qualitative research methods in the social sciences [Sosyal bilimlerde nitel araştırma yöntemleri] (9th Edition). Ankara: Seçkin Publishing. 
Akçamete, G., \& Kargın, T. (1996). Determining the needs of mothers of children with hearing impairments[İsitme engelli çocuğa sahip annelerin gereksinimlerinin belirlenmesi]. Ankara University Faculty of Educational Sciences Journal of Special Education,, 2(2), 7-24.

Blue-Banning, M., Summers, J. A., Frankland, H. C., Nelson, L. L., \& Beegle, G. (2004). Dimensions of family and professional partnerships: Constructive guidelines for collaboration. Exceptional Children, 70(2), 167-184. doi: 10.1177/001440290407000203

Brantlinger, E., Jimenez, R., Klingner, J., Pugach, M., \& Richardson, V. (2005). Qualitative studies in special education. Exceptional Children, 71(2), 195-207. doi: 10.1177/001440290507100205

Büyüköztürk, Ş., Kılıç Çakmak, E., Akgün, Ö. E., Karadeniz, Ş., \& Demirel, F. (2012). Scientific research methods [Bilimsel araştırma yöntemleri] (11th Edition). Ankara: Pegem Academy.

Desimone, L. (1999). Linking parent involvement with student achievement: Do race and income matter? Journal of Educational Research, 93(1), 11-30.

Halle, T. G., Kurtz-Costes, B., \& Mahoney, J. L. (1997). Family influences on school achievement in lowincome, African American children. Journal of Educational Psychology, 89(3), 527-537.

Kargın, T., Akçamete, G., \& Baydık, B. (2001). Determining the needs of families of preschool children with hearing impairments in the transition to kindergarten[Okulöncesi yaşta işitme engelli çocuğu bulunan ailelerin anasınıfına geçiş sürecindeki gereksinimlerinin belirlenmesi]. Ankara University Faculty of Educational Sciences Journal of Special Education, 3(1), 13-24.

MoNE. (2006). Special Education Services Regulation [Özel Ĕgitim Hizmetleri Yönetmeliği]. Official Gazette dated 31.05.2006 and numbered 26184.

Lai, Y., \& Vadeboncoeur, J. A. (2013). The discourse of parent involvement in special education: A critical analysis linking policy documents to the experiences of mothers. Educational Policy, 27(6), 867-897. doi: $10.1177 / 0895904812440501$

Selimoğlu, O. G., Özdemir, S., Töret, G., \& Özkubat, U. (2013). An examination of the views of parents of children with autism about their experiences at the post-diagnosis period of autism. International Journal of Early Childhood Special Education, 5(2), 129-167.

Simon, B. S. (2001). Family involvement in high school: Predictors and effects. Nassp Bulletin, 85(627), 819.

Summers, J. A., Gavin, K., Hall, T., \& Nelson, J. (2003). Family and school partnerships: Building bridges in general and special education. In F. E. Obiakor, C. A. Utley, \& A. E Rotatori (Eds.), Advances in special education: Psychology of effective education for learners with exceptionalities (pp. 417-445). Stamford, CT: JAI Press

Tekinarslan, İ. C.., \& Bircan, Ö. (2009). A study on needs of parents with mentally retarded children in transition to kindergarten [Zihin engelli çocukların anasınıfına geçiş sürecinde ebeveyn gereksinimlerinin belirlenmesi]. Bolu Abant İzzet Baysal University Journal of Faculty of Education, $9(1), 63-75$.

Trusty, J. (1999). Effects of eighth-grade parental involvement on late adolescents' educational expectations. Journal of Research \& Development in Education, 32(4), 224-233.

Vural, S., \& Yücesoy, Ș. (2004). The effects of preparations of joining into the European Union on legislation of services to be provided individuals with special needs in Turkey [Türkiye'de özel gereksinimli bireylere yönelik hizmetlerin yasal yapılanmasında Avrupa Birliğine uyum çabalarının yansıması]. Anadolu University Journal of Social Sciences, 3(1), 141-157.

Yassıbaș, U., \& Çolak, A. (2019). An in-depth analysis of the life experiences of parents with children with autism spectrum disorder. Education and Science, 44(198), 435-467. doi: 10.15390/EB.2019.7366 